\title{
Marian Devotion as a Form of Legitimization of the Imperial Authority
}

\author{
Dragoș BoICU*
}

The present research addresses matters concerning the relationship between Church and state during the reign of Theodosius II of Rome, analyzing especially the case of legitimization of the imperial authority found in the first half of the fifth century when the Empress Pulcheria tried to identify herself with the Virgin Mary before her subjects in order to further maintain control of the state alongside her brother, Theodosius II. This paper also attempts to connect the problem of the political experiment with the development of a Marian devotion in Constantinople as a solution for pagan cults' inculturation, reassessing Nestorius' reaction in parallel with the position of Epiphanius of Salamina.

Keywords: Virgin Mary, Pulcheria, Theodosian dynasty, imperial ideology, civic religion, inculturation

The Edict of Mediolanum provided to all subjects of the Roman Empire freedom to profess any faith, but also created conditions conducive to the institutionalization of Christianity. "Surrendering" to the state, the Church became part of the mechanism of imperial propaganda and was used to justify different public identities by the emperors as christianissimi principes. This mechanism could already be observed during the Constantinian dynasty and it was in some way excused by the given political, religious, and ideological context. As the process of Christianisation of the Roman Empire continued, so the political experiments went on during Theodosius the Great and his descendents as a reply to the Gothic crisis. A very special case of legitimization of the imperial authority is to be found in the first half of the fifth century when the Empress Pulcheria tried to identify herself with the Virgin Mary before her subjects in order to further maintain state control alongside her brother, Theodosius II.

Arcadius's death on May 1 ${ }^{\text {st }}, 408$ A.D. landed the Theodosian dynasty in a new impasse. Theodosius II, the 7 years old emperor (born on April 10 ${ }^{\text {th }}$, 401 A.D.), was in an odd situation that became more precarious as Pulcheria (399-453) and, finally, the other two sisters Arcadia (400-444) and Marina (403-449) approached marriageable age ${ }^{1}$, leaving room for the possibility

\footnotetext{
* Dragoș Boicu, Research Centre for Theology, Lucian Blaga University of Sibiu, Romania. Contact details: Mitropoliei 35 - Sibiu 550179, Romania; e-mail: dragosbcu@yahoo.com

${ }^{1}$ In late Antiquity girls could be engaged as early as the age of 7 and legally be married at 12, see: Gillian Clark, Women in Late Antiquity: Pagan and Christian Lifestyles, Oxford 1994, p. 13.
} 
that an ambitious politician could arrange a marriage which would destroy the dynastic independence ${ }^{2}$, or might even bring a new dynasty. Sozomen even expresses his surprise that "thus was the Eastern Empire preserved from the evils of war, and governed with high order, contrary to all expectations, for its ruler was still young"3.

\section{Aelia Pulcheria Augusta - the vow of chastity as a political solution}

Although it has been characterized by political stability (through successful negotiations with the Persian king Yazdgard I), urban development (through the construction of the wall of Theodosius, Honorius' baths, and other buildings), and cultural flourishing ${ }^{4}$, the regency of Flavius Anthemius, the Praetorian prefect of the Orient since 405 A.D. tended to turn into a parallel monarchy, most likely targeting a union with the Imperial House through the marriage of Pulcheria with his son Flavius Anthemius Isidorus. In order to counter the imperial official's manoeuvres and to save the dynasty, in 412 or 413 A.D. Pulcheria "first devoted her virginity to God, and instructed her sisters in the same course of life. To avoid all cause of jealousy and intrigue, she permitted no man to enter her palace [through marriage]" ${ }^{5}$. The gesture had a solemn character, God himself, the priests, and all the subjects being called upon to witness it, and was sealed by the offering of a golden altar decorated with precious stones to the Great Church of Constantinople. Sozomen says that this holy table was engraved with the text of the oath "so that it might be patent to all". It is estimated that Pulcheria chose to take this vow in order to keep as much power as she could. Otherwise she would have had to give it to her potential husband, since a married woman had to relinquish the political powers in favour of her spouse.

Sozomen stated repeatedly in the first chapter of the ninth book of his History that the piety of Pulcheria and her sisters earned divine favour for Theodosius, protecting him and keeping the Empire united in a tumultuous period, when the West was gradually crumbling under the pressure of migrating peoples ${ }^{7}$. Sozomen's biased presentation ignores the efforts of Anthemius and

${ }^{2}$ Kenneth G. Holum, "Pulcheria's Crusade A.D. 421-422 and the Ideology of Imperial Victory”, in: Greek Roman and Byzantine Studies 18 (2/1977), p. 158.

${ }^{3}$ Sozomen, Historia Ecclesiastica, IX, 6, PG 67: 1608.

${ }^{4}$ Socrates, Historia Ecclesiastica, VII, 1, PG 67: 763.

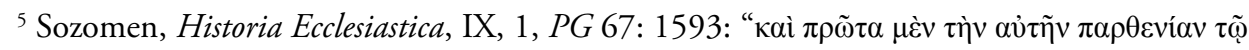

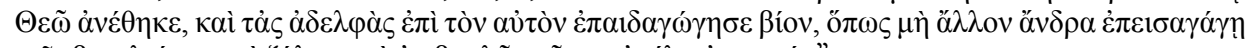

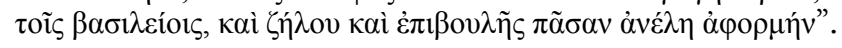

${ }^{6}$ Ibidem, IX, 1, 1, PG 67: 1593.

${ }^{7}$ Ibidem, IX, 1, 3, PG 67: 1594-1597. 
focuses on the acute political sense and the maturity of Pulcheria, who had assumed regency since 414 A.D. The account focuses on how the young princess "providentially" inspired her brother and strove "to lead him into piety, and to pray continuously; she taught him to frequent the church regularly, and to honour the houses of prayer with gifts and treasures; and she inspired him with reverence for priests and other good men, and for those who, in accordance with the law of Christianity, had devoted themselves to philosophy" ${ }^{8}$. Moreover, since 412 A.D. she removed the eunuch Antiochus from the position of praepositus sacri cubiculi, who was primarily responsible for the education of Theodosius, most probably because he tried to arrange the marriage of the princess with Anthemius Isidorus ${ }^{9}$ and so Pulcheria remained in charge of the instruction of her brother.

Pulcheria's proclamation as Augusta on July $4^{\text {th }}, 414$ A.D. by her younger brother, is preceded by the removal from the political scene of Anthemius Isidorus at the end of March 413 and of Flavius Anthemius, last mentioned on April $18^{\text {th }}, 414^{10}$, who was replaced in the office of praetorian prefect by Monaxius until the end of November 414, and then by Aurelianus, the faithful collaborator of Eudoxia during the Gothic crisis. He would contribute significantly to the strengthening of Pulcheria's authority, unveiling on December $30^{\text {th }}, 414$ the young queen's bust in the senate of Constantinople between Honorius' and Theodosius' statues ${ }^{11}$. The gesture can be considered analogous to the inauguration of Eudoxia's silver statue in autumn $403^{12}$. Both mother and daughter were portrayed in a very similar way in the numismatic representations, dominated by the idea of a Deo coronata, which suggested that the Empress had a sacred dominion (basileia) given by dextera Dei ${ }^{13}$.

Despite her young age Pulcheria managed to assert herself as a political authority, skilfully managing all the state affairs ${ }^{14}$, especially the religious life of the Empire, which was one of the major areas of interest of the young

${ }^{8}$ Ibidem, IX, 1, 1, PG 67: 1593.

${ }^{9}$ K. G. Holum, Theodosian Empresses. Women and Imperial Dominion in Late Antiquity, Berkeley-Los Angeles-Oxford 1982, p. 94.

${ }^{10}$ Alan Cameron, Jacqueline Long, Barbarians and Politics at the Court of Arcadius, BerkeleyLos Angeles-Oxford 1993, p. 400.

11 Chronicon paschale, anno 414, in: Ludovic Dindorf (ed.), Corpus Scriptores Historiae Byzantinae 32, Bonn 1831, p. 571.

${ }^{12}$ Sozomen, Historia Ecclesiastica, VIII, 20.

${ }^{13}$ K.G. Holum, Theodosian Empresses, p. 97.

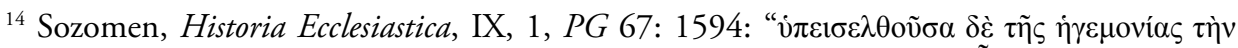

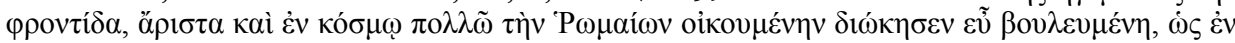

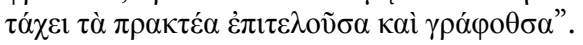


Empress. Sozomen states in his praising style that Pulcheria "provided zealously and wisely that religion might not be endangered by the innovation of spurious dogmas. That new heresies have not prevailed in our times, we shall find to be due especially to her" ${ }^{\prime 15}$.

After the appointment of Aurelian as the new praetorian prefect, the young Augusta was concerned with issuing decrees aimed against the heathen and the Hebrew, showing her Christian fervour ${ }^{16}$. Unlike the Empress Eudoxia, Pulcheria and her two sisters, Arcadia and Marina, had a keen interest in religious matters, adopting a pious way of life which transformed the imperial court in a quasi-monastic space. Although Pulcheria formally transferred the political authority to her brother Theodosius as her regency ended in 416, the Augusta continued to pull the strings of the empire. Paradoxically, as Arcadia and Marina embraced the same quasi-monastic way of life of their older sister, the moral and spiritual authority of the Augusta grew even more. Pulcheria's "godliness" is the constant element around which the political and religious cohesion of the subjects established itself, and the bishops of the Church felt the need to emphasize this form of patronage, sanctioning a new ideology which was engrafted on the imperial ceremony.

Even if she chose to isolate herself politically after the year 425 A.D., Pulcheria still dominated the religious life of Constantinople, further exercising a form of ecclesiastical patronage. The "care" or the protection offered by the Empress to the Church was recognized and legitimized during the time of Archbishop Atticus, who in 416 A.D., according to the Chronicle of Marcellinus, addressed to the Augusta and her sisters an "exceptional" treaty (De Fide et Virginitate) ${ }^{17}$ now lost. It seems, however, that the author of this text was the erudite deacon Proclus, Atticus' secretary, who in his turn became archbishop of the city between 434 and $446^{18}$. Kenneth Holum states that Socrates' text ${ }^{19}$ reveals exactly Proclus' paternity of the treaty, because the

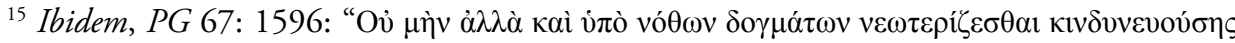

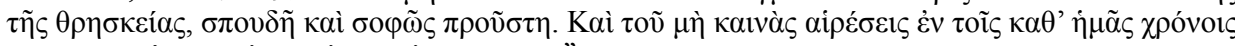

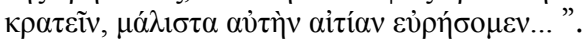

${ }^{16}$ Geoffrey S. Nathan, “Theodosius II (408-450 A.D.)”, in: De Imperatoribus Romanis Atlas, http://www.roman-emperors.org/theo2.htm. last viewed 20.06.2013.

${ }^{17}$ Marcellinus Comes, Chronicum, A.D. 416, PL 51: 923: "Atticus Constantinopolitanus episcopus scripsit ad reginas, Archadii imp. filias, de Fide et Virginitate librum valde egregium, in quo praeveniens Nestorianu dogma impugnat". The information is resumed by Gennadius of Marsillia in De viris illustribus, 52, PL 58: 1088.
}

${ }^{18}$ Ioan I. Ică jr, "Imnul Acatist - mistagogie şi istorie", in: Ermanno M. Toniolo, Acatistul Maicii Domnului explicat: Imnul şi structurile lui mistagogice, presentation and translation by Ioan I. Ică jr, Sibiu 2009, p. 34.

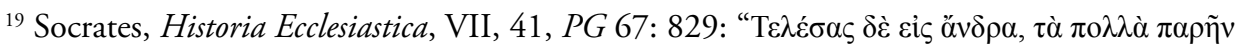




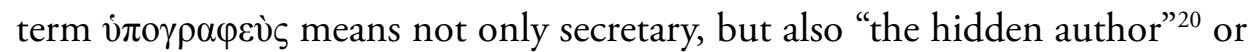
"the person who drafted or signed a document on behalf of someone else" 21 .

During Atticus' tenure ${ }^{22}$, at Pulcheria's request several innovations were introduced into the worship of the Constantinopolitan Church, the best known of which were the robe or the veil ( $\sigma \tau 0 \lambda \eta \dot{~ / ~ \mu \alpha \varphi o ́ p ı o v ~ / ~ \sigma \kappa \varepsilon ́ л \eta) ~ c o v e r i n g ~}$ the Holy Table that Theodosius' older sister previously wore, respectively the image (icon) of Augusta placed above the $\operatorname{altar}^{23}$. This representation is considered by Vasiliki Limberis as the most powerful form of Pulcheria's symbolic presence, focused around a sign of the civic religion (the image of the emperor / Empress), transferred from a political to the religious space ${ }^{24}$. The two types of ritual - civic and ecclesiastical - converged into a new political experiment through which "Pulcheria transferred part of the civic ceremonial into the ecclesiastical sphere, to which she had dedicated her life. She did not, however, change any of the rituals connected with her image to accommodate the Church. It is significant that she acted in her imperial role to do this. She chose to retain this symbol, her portrait, to gain honour, not in the outside world of the city, but in her chosen sphere, the Church"25.

The treaty attributed to Atticus seems to offer some theological and ideological ground for the imperial protectorate and for Pulcherias' preeminence in the Church, and the placing of Augusta's image over the altar merely validated the insertion of the civic element into the cult, turning the ecclesiastical space into the Empress's public arena. According to Vasiliki Limberis, the shaping of a civic character of the Christian religion was conducted simultaneously with the emergence of the Virgin's cult in Constantinople, or as Father Ioan I. Ică jr. synthesized "Pulcheria has turned her personal veneration of the Virgin Mary into a religious civil cult, with processions, vigils, eulogies, and special hymns"26.

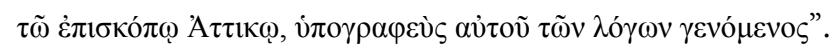

${ }^{20}$ K.G. Holum, Theodosian Empresses, p. 141.

${ }^{21}$ Liddell-Scott-Jones, Lexicon of Classical Greek - Perseus Digital Library (20.06.2013)

${ }^{22}$ Vasiliki Limberis, Divine Heiress. The Virgin Mary and the creation of Christian Constantinople, $2^{\text {nd }}$ edition, New York 2002, p. 49.

${ }^{23}$ Barhadbshabba Arbaya, 27, in: Patrologia Orientalis XI, Paris 1915, p. 565.

${ }^{24}$ V. Limberis, Divine Heiress. The Virgin Mary, p. 50: "Pulcheria's most potent presence in the city".

${ }^{25}$ Ibidem, p. 50.

${ }^{26}$ I. I. Ică jr, "Imnul Acatist - mistagogie şi istorie”, p. 49. 


\section{The Marianic cult in Constantinople - a solution for the inculturation of pagan cults}

Vasiliki Limberis believes that this specific and exclusive Constantinopolitan process was made possible only by overlapping the cult of the Virgin Mary and a religious amalgam centred on the worship of goddesses who dominated the spirituality of the populations on both sides of the Bosporus $^{27}$, a name derived from a corrupted form of the adjective $\varphi \omega \omega \sigma \varphi \rho \circ \varsigma$ (light bearer), an epithet dedicated to the pre-Olympian goddess Hecate, the patroness of crossroads, fire, light, magic, and necromancy, who ruled earth, sea, and air, who played the role of a universal saviour in the Hellenistic mythology, and was considered the mother of the angels and the soul of the

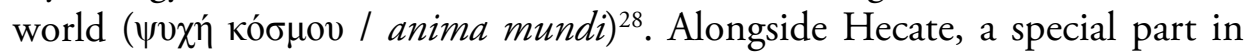
Byzantium's pantheon was occupied by the goddesses Rhea (the mother of the Olympian gods: Zeus, Poseidon, Hades, etc.) and Tyche (an oceanic deity, the daughter of Oceanus and Tethys, governing the fortune and prosperity of a city, its destiny, lat . - Fortuna) ${ }^{29}$.

Eusebius of Caesarea triumphantly stated that Constantine "being full of the breath of God's wisdom, which he reckoned a city bearing his own name should display, he sought to purge it of all idol-worship, so that nowhere in it appeared those images of the supposed gods which are worshipped in temples, nor altars foul with bloody slaughter, nor sacrifice offered as holocaust in fire, nor feasts of demons, nor any of the other customs of the superstitious" ${ }^{30}$. Augustine exaggerates as well saying that Constantinople was "devoid of any shrine or temple of demons"31. But it seems that some forms of polytheistic spirituality survived as a civil religious ceremony. Constantine himself inaugurated a statue of Tyche portrayed as patron of the city ${ }^{32}$, which came to be known as "Tyche Constantinopolis"33, the eastern replica of the goddess Roma (Roma Dea), a genius' personification of the new capital, which

\footnotetext{
${ }^{27}$ V. Limberis, Divine Heiress. The Virgin Mary, pp. 123-142.

${ }^{28}$ See: Sarah I. Johnston, Hekate Soteira: a Study of Hekate's Roles in the Chaldean Oracles and Related Literature, in col. American Classical Studies, 21, Atlanta 1990.

${ }^{29}$ V. Limberis, Divine Heiress. The Virgin Mary, pp. 124-130.

${ }^{30}$ Eusebius, Life of Constantine, III, 48, introduction, translation, and commentary by Averil Cameron and Stuart G. Hall, Oxford 1999, p. 140.

${ }^{31}$ Augustin, De Civitate Dei, V, 25, in: Collectio selecta SS. Ecclesiae Patrum, vol. CIX, Patres Quinti Ecclesiae Saeculi. S. Augustinus, vol. II, D. A. B. Caillau, D. M. N. S. Guillon (ed.), Paris 1835, p. 267: "sed sine aliquo daemonum templo simulacroque".

${ }^{32}$ Chronicon paschale, anno 330, Ludovic Dindorf (ed.), p. 530.

${ }^{33}$ V. Limberis, Divine Heiress. The Virgin Mary, p. 50.
} 
was mostly an abstract concept endowed with sufficient symbolic meaning to legitimize the exceptional position of the city on the Bosporus.

During the fourth century there was a clear tendency to identify the concept of Constantinopolitan genius with Tyche, by borrowing her iconographic attributes so that the representations of the personified Constantinople would be identical to the oceanic deity: a female figure wearing a crown on her head and a sceptre in her hand sits on a throne with feet supported by a ship's keel, whose bowsprit always comes out. This type of representation was used since the time of Constantine the Great and was known during the reigns of Constans, Constantius, Valentinian I, Valens, Valentinian II, Arcadius, and Theodosius II. After the Council of Chalcedon (451 A.D.) the numismatic motif was replaced by other models, appearing only sporadically a century later during the time of Justin II (565-578 A.D.).

The tendency to adapt or to inculturate pagan elements in the Church's cult could be seen from this devotion which the emperors who followed Constantine had for the Constantinopolitan genius and the predilection to dedicate "churches" to impersonal powers of a very ambiguous and

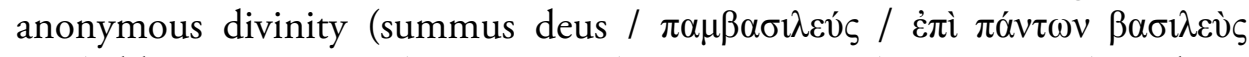

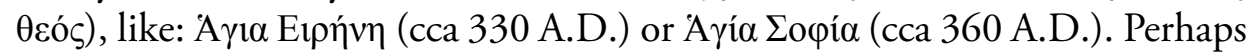
the most relevant expression of this transfer of elements from the civic into the Christian religious space remains the very noun $\lambda \varepsilon$ cıovpría that initially designates any form of "public service".

The lack of sufficient information only gives way to assumptions and more or less inspired hypotheses. Following the direction set by Helmut Koester, an eminent professor at Harvard Divinity School, Vasiliki Limberis studied the numismatic and written sources and concluded that the devotion for the goddess Tyche Polyade was overlapped on the ambiguous syncretism of ancient Byzantium and even came to be identified with Rhea, "the mother of the gods"34. Furthermore it can be assumed that in the first quarter of the fifth century the cult of the Virgin reached such a magnitude because with the imperial and theological support, it was most likely to overlap the Marianic cult over the civic cult dedicated to the personification of an abstract concept like the destiny of Constantinople, which plays the traditional role of Dea Roma, reflecting the power of the Empire. The veneration of the Mother of God fits perfectly to this syncretistic construct that combines the solar qualities of Hecate, the political symbolism attributed to Tyche Polyade, the virginity protected by Artemis, Rhea's divine maternity and the virginal

\footnotetext{
${ }^{34}$ Ibidem, pp. 19-21.
} 
birth of Athena. In Antiquity in the Mediterranean area there was a variety of worshiped goddesses who were at one time regarded as virgin mothers: the parthenogenesis was a feature that characterized Hera and Artemis, Gaia, Persephone and the gnostic Sophia ${ }^{35}$.

The variety of devotions to all these goddesses is attested in ancient Byzantium, being successively merged into a long process so that into the persons of goddesses Tyche and Rhea were merged Athena, Hecate, Demeter / Kore and even Isis, and in the second century A.D. Dionysius of Byzantium revealed a new phase of the local syncretism, a synthesis between Tyche and Rhea, which culminated during Constantine the Great with the identification of Tyche and the Constantinopolitan genius.

At the beginning of the sixth century the pagan philosopher Damascius still believed in the presence of Tyche as he recorded the assassination attempt on Theodosius II, stating that Lucius, magister militum presentalis in Constantinople ${ }^{36}$, had intended to kill the young Augustus three times but failed when he saw "a large and sturdy woman who embraced Theodosius from behind" ${ }^{37}$. This feminine presence was identified by Kenneth Holum with the goddess Fortuna or her correspondent in the Greek pantheon, Tyche, or even a form of genius publicus ${ }^{38}$, an indistinct power generating and conserving the human society.

Considering the mix of mythological teachings which the devotion to the Holy Virgin overlapped, we can understand more easily Nestorius' reserve, who, coming from the Syrian space, could not agree to this specific and exclusive Constantinopolitan process whose concentrated expression was

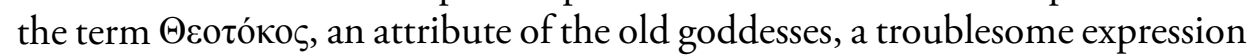
for the Syrian preacher:

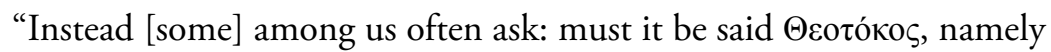
the begetter of God or the Mother of God, or, on the contrary $\dot{\alpha} v \theta \rho \omega \pi$ otókos, i.e. the begetter of human? Has God [a] Mother? [Then is] without guilt the pagan who assigns mothers to gods. Then Paul [is] a liar when he says about the divinity of Christ: «Without father,

\footnotetext{
${ }^{35}$ See: Marguerite Rigoglioso, Virgin Mother Goddesses of Antiquity, New York 2010.

${ }^{36}$ See: "Lucius 2", in PLRE, II, p. 692

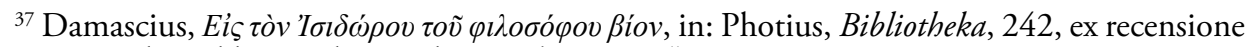

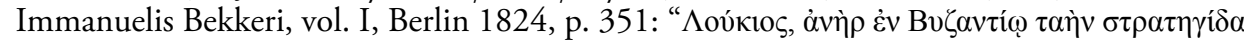

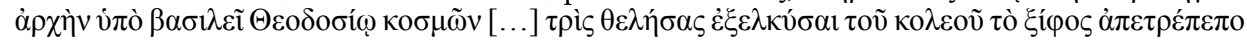

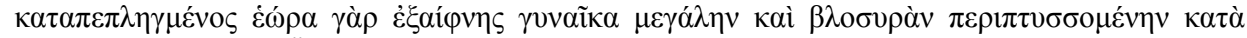

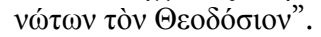

${ }^{38}$ K.G. Holum, Theodosian Empresses, p. 82. 
without mother, without descent». [But] Mary had not given birth to the divinity, for «that which is born of the flesh is flesh»" 39 .

It seems that Nestorius feared the possible deification of the Virgin

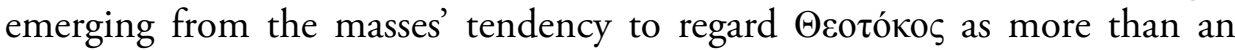
"instrument" for the Incarnation of the Logos and thus the Mother of God was "venerated directly for herself and for the assistance she might give mankind" 40 . The fear that a Marianic cult would gain autonomy and morph into a parallel religious current is more evident in another fragment attributed to Nestorius:

"I have already said many times that if any of you, or any of the simple-

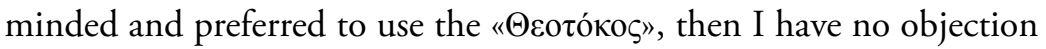
to the term, only do not make a goddess of the Virgin" ${ }^{\prime \prime}$.

This passage reminds of a text written by Epiphanius of Salamis in his monumental work Panarion, when he refers to the heresy of the Collyridians "who make offerings to Mary" in some parts of Scythia, especially in Thrace (the province where Constantinople was placed), from where it spread even in Arabia ${ }^{42}$. Vasiliki Limberis states that "the fact that Thrace and Scythia were the locations of strong, long-lived cults to Rhea and Demeter, coupled with the fact that the Collyridians had women clergy and rituals reminiscent of Demeter's cult, lead one to the hypothesis that Mary could have been syncretised into an original pagan goddess cult" ${ }^{43}$. So this syncretism resulted in an alleged Christian ritual with pagan reminiscences, served by priestesses,

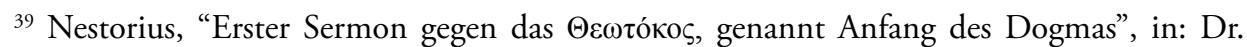
Friedrich Loofs, Nestoriana. Die Fragmente des Nestorius, Halle 1905, pp. 251-252: "in nobis

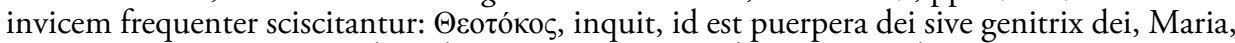

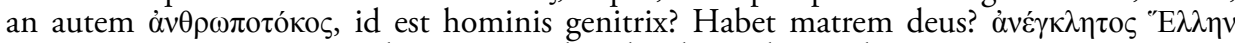

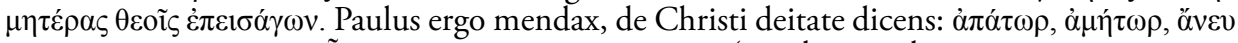

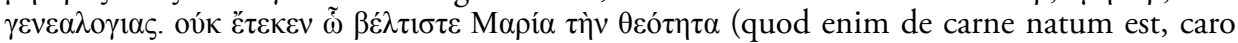
est)".

${ }^{40}$ Timothy E. Gregory, Vox populi. Popular Opinion and Violence in the Religious Controversies of the Fifth Centry A.D., Columbus 1979, p. 99.

${ }^{41}$ Nestorius, "Nicht sicher einzuordende Fragmente", III, in: Dr. Friedrich Loofs, Nestoriana,

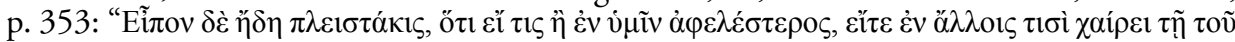

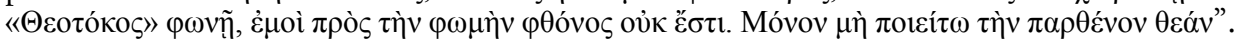

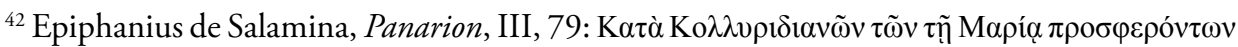

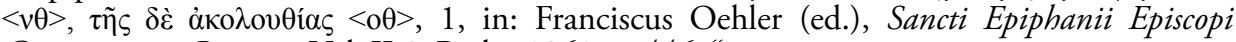

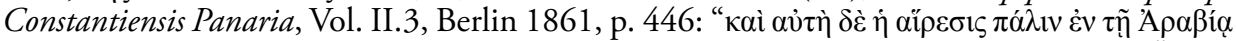

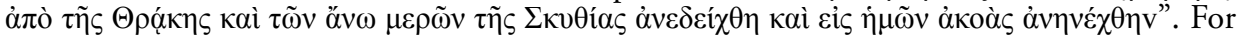
the English translation I have used The Panarion of Epiphanius of Salamis: De fide. Books II and III, translated by Frank Williams, $2^{\text {nd }}$ edition, Leiden 2013, p. 637.

${ }^{43}$ V. Limberis, Divine Heiress. The Virgin Mary, p. 120. 
and this is why, in the chapter about Collyridians, Epiphanius makes a Mariological presentation and tries to maintain a balance between the notion of honour ( $\tau \mu \eta \dot{n}, \tau \mu \alpha \dot{\omega} \omega)$ perfectly legitimate for the Virgin, and the worship or adoration ( $\pi \rho \circ \sigma \kappa v ́ v \eta \sigma ı \varsigma, \pi \rho \circ \sigma \kappa v v \varepsilon ́ \omega)$ strictly due to God:

"Yes, of course Mary's body was holy, but she was not God. Yes, the Virgin was indeed a virgin and honoured as such, but she was not given us to worship; she worships Him who, though born of her flesh, has come from heaven, from the bosom of his Father. And the Gospel therefore protects us by telling us so on the occasion when the Lord himself said, «Woman, what is between me and thee? Mine hour is not yet come» (Jn. 2:4). [For] to make sure that no one would suppose, because of the words, "What is between me and thee?» that the holy Virgin is anything more [than a woman], he called her «Woman» as if by prophecy, because of the schisms and sects that were to appear on earth. Otherwise some might stumble into the nonsense of the sect from excessive awe of the saint ${ }^{44}$.

[...] and even though Mary is all fair, and is holy and held in honour, she is not to be worshiped ${ }^{45}$.

[...] Mary [must be] honoured, [but only] God must be worshiped" 46 .

Referring to the Collyridians' cult, which consisted of offering bread on a square chair or a table, with a piece of cloth or a garment spread over $i^{47}$, and offering it in Mary's name, St. Epiphanius compares this liturgical deviation with a situation experienced by the prophets of the Old Testament:

"But again, these women are «renewing the potion for Fortune and preparing the table for the demon» (Is. 65:11) 48 $^{4}$ and not for God, as

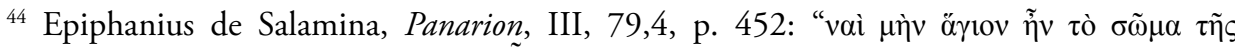

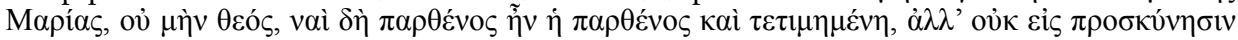

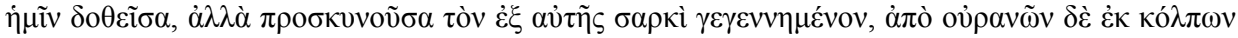

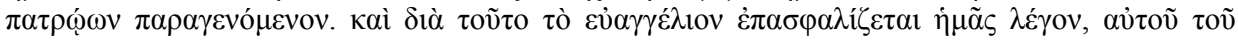

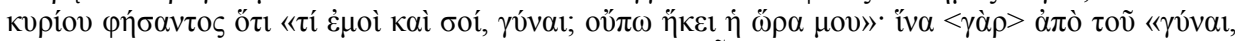

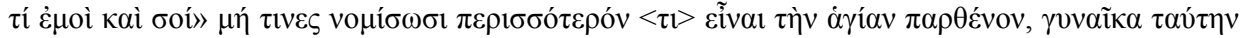

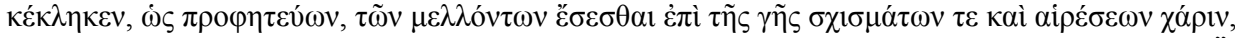

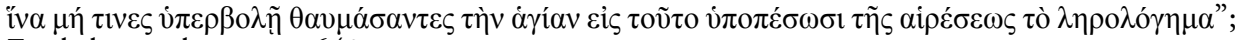
English translation, p. 640.

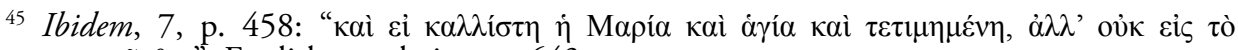
$\pi \rho \circ \sigma \kappa v v \varepsilon \tilde{\sigma} \theta \alpha$ ”, English translation, p. 643.

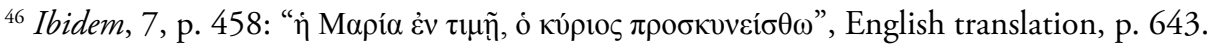

${ }^{47}$ Ibidem, 1, p. 446, English translation, p. 637.

48 Septuaginta uses Tyche as an equivalent for Gad, pan-Semitic god of fortune, mentioned
} 
the Scripture says. And they drink impious drinks as the word of God says, «And the women grind flour, and their sons gather wood to make cakes $^{49}$ for the host of heaven $»^{50}$ (Jer. 7:18). Such women should be silenced by Jeremiah, and not frighten the world. They must not say, "we honour the queen of heaven» (Jer. 51:18)"51.

According to St. Epiphanius the main cause of this aberration was the

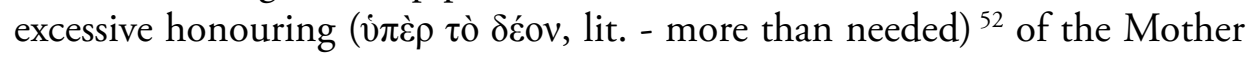
of God in the context of an inculturation phenomenon of various elements from endemic pagan cults.

These texts show that the veneration of the Virgin was still developing in the second half of the fourth century, but the existence of Marian devotion by the fourth century in Constantinople and Cappadocia is attested by Gregory of Nazianzus and Gregory of Nyssa ${ }^{53}$. Quite interesting is that the Constantinopolitan Mariology makes use of two concepts deeply rooted in the Christian tradition: a) the concept of the "New Eve", which had been used since the mid-second century by St. Justin Martyr, then by St. Irenaeus

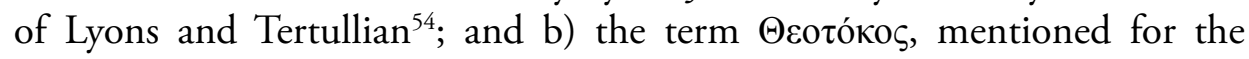
first time by Origen in his Commentary on the Epistle to the Romans, as Socrates tells us ${ }^{55}$, being used in nearly 60 other disputed texts (including by Epiphanius of Salamis) previous to the dispute triggered by the intransigence

in the Masoretic Text.

${ }^{49}$ Sacrificial cakes with raisins baked in baking tins made to look alike with goddess Astarte's face.

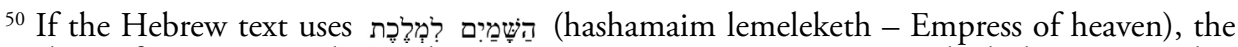

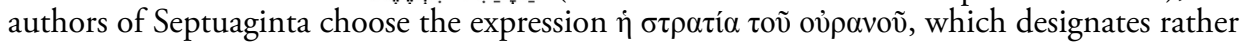
a "Heaven's army" (הַשַָׁמיִם צְברָא). However Jeremiah clearly refers to a feminine deity who

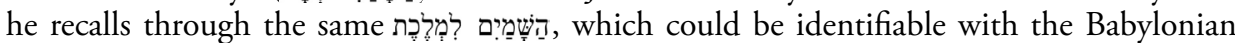
fertility goddess Ishtar, or the Canaanite deity Asherah, cf. Bob Utley, Study on Jeremiah 7, bible.org/seriespage/jeremiah-7, last viewed 13.06.2013.

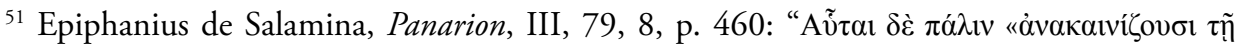

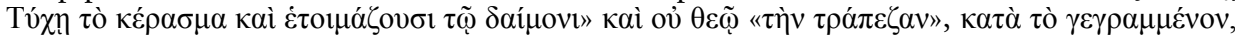

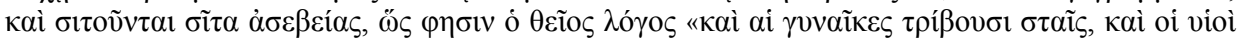

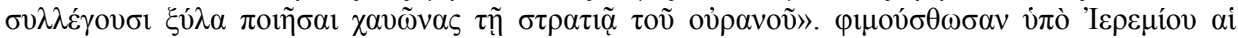

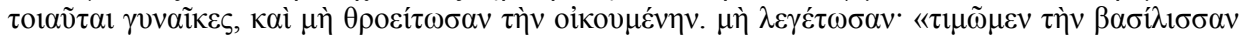

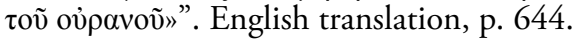

52 Ibidem.

53 See: Stephen Shoemaker, "The Cult of the Virgin in the Fourth Century: a Fresh Look at Some Old and New Sources", in: Sarah J. Boss, Chris Maunder (eds.), The Origins of the Cult of the Virgin Mary, London 2008, pp. 72-73.

${ }^{54}$ Leena Mari Peltomma, The Image of the Virgin Mary in the Akathistos Hymn, Brill, LeidenBoston-Köln, 2001, pp. 128-130.

55 Socrates, Historia Ecclesiastica, VII, 32. 
of Nestorius ${ }^{56}$.

It can be said that the synthesis of pagan and Christian elements achieved by the Marian cult in Constantinople really fits the "religion of Constantine", to which the eastern capital was dedicated ${ }^{57}$.

\section{Marian devotion and the shaping of a new imperial ideology}

It is generally known that the Christological doctrine of Nestorius ${ }^{58}$ originated in a misunderstanding of the Constantinopolitan Mariology and

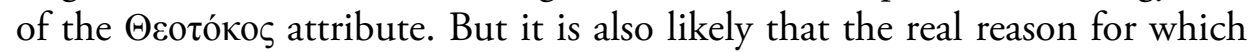
Nestorius challenged the Mariological teaching may have been an attempt to counteract the use of Marian symbols as means of legitimating a new ideology by Pulcheria. While Theodosius' power was legally defined and exerted through the complex bureaucratic apparatus, the military and diplomatic patronage, Pulcheria's $\beta \alpha \sigma i \lambda \varepsilon i ́ \alpha$ was more diffuse, limited to the network of social contacts which she had built during the her regency ${ }^{59}$.

The key of the new political construct was $\pi \alpha \rho \theta \varepsilon v i \alpha$ (the virginity), perceived as the best way to imitate the Virgin's virtue (imitatio Mariae) and to put into practice a theoretical and ideal model since the consecrated women identified themselves with the New Eve. Since the late fourth century A.D. ${ }^{60}$, it could be observed that the preserving of chastity had an increased importance as a mean of devotion so that Constantinople came to be called "the city of the virgins" ${ }^{1}$. It may be that Pulcheria's option for chastity was considered a gift bestowed to the Theodosian dynasty because such a way of life came from a divine vocation and the embracing of this path was ultimately a blessing from God $^{62}$.

During the fourth and fifth century A.D. the Church attempted to strike

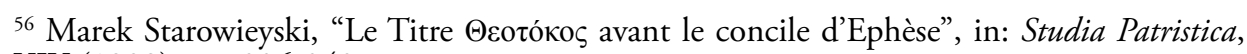
XIX (1989), pp. 236-242.

${ }^{57}$ See: Gilbert Dagron, Naissance d'une capitale, Paris 1974, p. 377.

${ }^{58}$ The problem regarding Nestorius is surely more Christological than Mariological, but since the issue of Nestorius' Christology has been extensively studied we leave aside the doctrinal elements on the relationship between nature and person in the Antiochian thinking.

${ }^{59}$ J.A. McGuckin, "Nestorius and the political factions of fifth-century Byzantium: factors in his personal downfall", in: Bulletin John Rylands Library, 78 (3/1996), p. 19.

${ }^{60}$ See also the case of the monastic community organized by St. Macrina in Cappadocia or the case of Olympia, which was ultimately ordained deaconess. See also J.A. McGuckin, "The Paradox of the Virgin-Theotokos: Evangelism and Imperial Politics in the fifth-century Byzantine World", in: Maria, 2.1 (2001), pp. 8-25.

${ }^{61}$ L.M. Peltomma, The Image of the Virgin Mary, p. 72.

${ }^{62}$ Roger Steven Evans, Sex and Salvation: Virginity as a Soteriological Paradigm In Ancient Christianity, p. 103. 
a balance in its anthropological teaching in order to free the woman from her gynaikeia recognizing her value and dignity as a creature of God, equal with man, and not only as a daughter of Eve, through whom the sin had entered the world, but also as a daughter of the New Eve, who brought the salvation of mankind carrying in her womb Christ, the Saviour ${ }^{63}$. The relationship

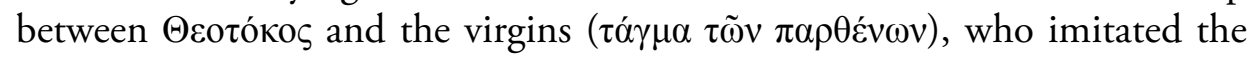
devotion of the archetypal Virgin, seems to have been so close that, according to homilies attributed to Atticus (but likely written by the same Proclus), the virgins will bear Christ in a mystical way as the Logos became flesh in the womb of Mary ${ }^{64}$. The text repeats an assertion of St. Gregory of Nazianzus, who during his short tenure in Constantinople (379-381) said at the Feast of the Nativity of Christ: "Christ [was born] of the Virgin; women embrace virginity to be (yourselves) mothers of Christ!" ${ }^{65}$ Elena Giannarelli makes it clear that at the beginning of the fifth century imitatio Mariae regarded not only unmarried women or virgins, but also married mothers and widows ${ }^{66}$.

Taking into account the cultural and religious context - both pagan and Christian - it is quite simple to accept Pulcheria's Marian devotion and only the question of the authenticity of this devotion remains open, since she was motivated to make the vow of chastity for the sake of her political interests, as shown in the writings of Socrates, Sozomen, and Theodoret ${ }^{67}$.

It might be said that Pulcheria continued the policy initiated by Theodosius the Great, which augmented the role of women and attempted the demilitarization of the imperial ideology ${ }^{68}$, as it could be seen when Aelia Flaccilla, Eudoxia, and Pulcheria were proclaimed Augustae, because it was thought that they could contribute to the governance of the Empire through

${ }^{63}$ K.G. Holum, Theodosian Empresses, p. 140.

${ }^{64}$ See: J. Lebon, "Discours d'Atticus de Constantinople «Sur la Sainte Mère de Dieu»", in: Muséon 46 (1933), p. 190: "At vos quoque, mulieres, quae in Christo regeneratae estis et omnes impietatis sordes deposuistis, atque benedictionis sanctissimae Mariae participes factae estis, excipite, vos quoque, in utero fidei eum, qui hodie ex Virgine natus est; nam ipsa quoque sancta Virgo Maria, cum prius per fidem uterum dilatasset, postea habitaculo excepit Regem mundi, cum membra sua regno digna reddidisset”.

${ }^{65}$ St. Grigorie de Nazianz, In Nativitatem vel in Theophania, PG 36: 313: "Xpıбò̀

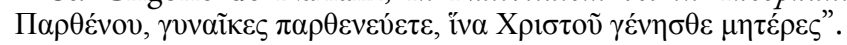

${ }^{66}$ Elena Giannarelli, "Maria come «exemplum» per la tipologia femminile nei sec. IV-V”, in: Felici (1989), pp. 233-246.

${ }^{67}$ Judith Mary Foster, Giving Birth to God: The Virgin Empress Pulcheria and Imitation of Mary in Early Christian Greek and Syriac Traditions (Degree of Magisteriate in Arts Paper), unpublished, Concordia University, Montreal 2008, note 274, p. 67.

${ }^{68}$ K.G. Holum, Theodosian Empresses, p. 79. 
the power of their "godliness"69, being able to ensure the loyalty of the masses and the popularity of the dynasty. This phenomenon must be regarded in connection with the process of Germanization or "barbarization" of the imperial troops, when the generals are mostly Goths, Franks, and from other barbarian tribes, and the army's loyalty had to be maintained if not by brute force and military genius, at least through a distinct superhuman status, and using the Deo Coronata motif emphasizes precisely that supernatural element, necessary to achieve an authority level inaccessible to the barbarian generals.

Judith Mary Foster had the fortunate inspiration to put together the thesis of Kenneth Holum ${ }^{70}$, who explained Pulcheria's option for the vow of chastity as a strategic gesture to save the dynasty, and the views outlined at the end of the twentieth century and beginning of the twenty-first, according to which the stressing of Pulcheria's political motivation in order to achieve her goals through chastity is unilateral and excessive ${ }^{71}$, even more so when she is not a singular case, but fits perfectly to the emerging trend of imitatio Mariae at the beginning of the fifth century among Roman aristocratic women.

What individualizes the Empress is the attempt to impose her public image into the sacred space; her "icon" was placed above the Holy Table in the Great Church of Constantinople, a place which later was reserved in the iconographic plan for the Virgin's representation. Basically Pulcheria's image reigned in the church like the emperor's statue and the imperial insignia dominated the Hippodrome and the Senate. Thus the Empress "was one of the very few women who had the means to challenge (subtly but visibly) the social constraints of their era and craft a public persona whose claim to holiness was evident throughout their lifetime"72, similar to the Virgin Mary's way to exemplify the holiness of a life dedicated to God.

It cannot be excluded that posterity assimilated Pulcheria's protectorate and her attempt to identify the Holy Virgin in a sustained imitatio Mariae to such an extent that finally there took place a transfer of imperial epithets and symbols on the Mother of God. This way the Virgin's representation took the place of Pulcheria's "icon", being assigned in decorating the altar apse especially after the development of the Byzantine architectural style, characterized by

${ }^{69}$ J.M. Foster, Giving Birth to God, p. 43.

${ }^{70}$ K.G. Holum, Theodosian Empresses, p. 103.

${ }^{71}$ L.M. Peltomma, The Image of the Virgin Mary, p. 72.

${ }^{72}$ Antonia Atanassova, “Orthodox Women's Defense of the Theotokos: The Case of Empress Pulcheria and the Council of Ephesus", in: Philanthropy and Social Compassion in Eastern Orthodox Tradition: Papers of the Sophia Institute Academic Conference, New York 2010, p. 138. 
Cosmas Indicopleustes (sixth century A.D.) as a parallelepiped crowned with a dome - a synthesis of the two ultimately irreconcilable volumes: the cube and the sphere - after the world's image ${ }^{73}$. Becoming the most important place of the church as the likeness of the sky above the heavens the dome hosted the Saviour's image, leaving an empty place on the hemispherical semi-dome above the altar and this area was dedicated to the Virgin's image, the segment of a sphere symbolizing the space where the divine let itself be circumscribed as it did already in the womb of the Virgin Mary.

Also the Empress' garment became the altar's "cover" and protected, like a canopy, not only the Holy Table but the whole Constantinople, the whole Church and the whole Empire, anticipating the Virgin's veil, which was wore in procession as a symbol of protection together with the Hodegetria icon displayed on the city walls during the siege of 626, 678 and 718 A.D. Nicholas Constas establishes a "striking" parallel between Pulcheria and the Virgin Mary: as her model (the Holy Virgin) who had woven a garment of flesh that folded around the divinity, the virgin Empress has woven a garment of cloth to serve as a covering for the Holy Table, and as a symbolic shroud over the body of $\mathrm{Christ}^{74}$. But even this $\sigma \tau \mathrm{\tau} \lambda \hat{\eta}$ could be considered an "icon" or a foreshadowing of the Marian relic (assigned in different sources as $\mu \alpha \varphi$ ópıov,

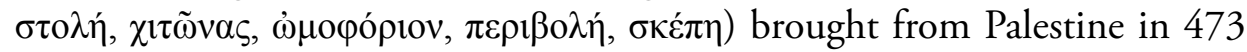
and deposited in an annex (A $\gamma^{\prime}$ os $\Sigma$ opós) at the Church of Blachernai ${ }^{75}$, built by Pulcheria in 450 and completed after her death $(\dagger 453)$ by Marcianus $(\dagger 457)$. Of course, there is no evidence that the Empress would have been considered establishing a relationship between her garment and the Virgin's covering veil ( $\sigma \kappa \varepsilon ́ \pi \eta)$, but we cannot ignore the coincidence.

The protectorate that the Augusta once exercised from then on became an attribute of the Theotokos, an idea embodied in notions like shelter,

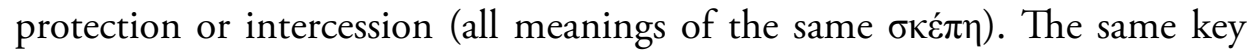
could be used to interpret the words in the beginning of the first Kontakion of the Akathist to the Most Holy Theotokos of All Protection, the Holy Virgin is

\footnotetext{
${ }^{73}$ Cosmas Indicopleustes, Christian Topography, IV, translated from the Greek, and edited, with notes and introduction by J. W. McCrindle, 1897, p. 129: "To the extremities on the four sides of the earth the heaven is fastened at its own four extremities, making the figure of a cube, that is to say, a quadrangular figure, while up above it curves round in the form of an oblong vault and becomes as it were a vast canopy".

${ }^{74}$ Nicholas Constas, Proclus of Constantinople and the Cult of the Virgin in Late Antiquity: Homilies 1-5, Texts and Translations, Leiden 2003, p. 134.

${ }^{75}$ For the different versions of the legend regarding the $\mu \alpha \varphi$ ópıv, and the nature of this garment, see: Stephen J. Shoemaker, "The Cult of Fashion: The Earliest «Life of the Virgin» and Constantinople's Marian Relics”, in: Dumbarton Oaks Papers, Vol. 62 (2008), pp. 53-74.
} 
called "O Chosen by the pre-eternal God, Queen of heaven and earth higher than all creation, who hast in days past entered praying into the Church of the Blachernae $^{76}$ we, offering Thee due veneration with thanksgiving, flee with faith and compunction under Thy shining vestment for we lie in darkness. And Thou who hast invincible power dost set us free from every affliction that we may cry to Thee: Rejoice, our Joy, protect us from every ill by Thy precious Veil". Even at a distance of several decades or even centuries these elements show that the relationship $\beta \alpha \sigma i ́ \lambda \iota \sigma \sigma \alpha-\pi \alpha \rho \theta \varepsilon \dot{v o \varsigma}-\Theta \varepsilon o \tau o ́ \kappa o \varsigma$ was crystallized during Pulcheria's reign and the identification of the Empress with the Virgin Mary presents a mutual communication of the attributes of the two women.

Based on the vow of chastity which she took in the great cathedral ${ }^{77}$ and on this unique relationship constructed by inserting the imperial symbols in the Church, Pulcheria seems to have presented herself as a kind of earthly image of the Virgin Mary. Unlike the previous Empresses, the Augusta used her status to receive the Eucharist at Easter inside the altar among priests and her brother, for which gesture Nestorius criticized her saying that the altar was reserved exclusively for priests. The Empress apparently wanted to abuse of this parallel created between her and the Mother of God, emphasizing their consubstantiality and therefore the privileges due to her, and asked rhetorically "Have I not born God?" (comparing herself to the mystical birth of Christ in a devoted virgin), and Nestorius replied "You have born Satan"78. Antonia Atanassova deems it significant that when she asked for access to the "Holy of Holies" Pulcheria did not refer to the imperial privilege befitting an Empress, but strictly to her vocation as a Christian woman and virgin - a sufficient quality from her point of view to approach a place assigned exclusively for priests. The incident seems to indicate "that by identifying with Mary female candidates for sainthood like Pulcheria could succeed in subverting the existing order of powers by appealing to a powerful female figure whose special relationship with God enabled them to plead for what a male-dominated society would ordinarily refuse them (i.e. entering the sanctuary)" 79 .

\footnotetext{
${ }^{76}$ Reference to a miracle during the reign of Emperor Leon VI (886-912).

77 Barhadbshabba Arbaya, 27, p. 565; Kathryn Chew, "Virgins and Eunuchs: Pulcheria, Politics and the Death of Emperor Theodosius II", in: Historia, nr. 55 (2/2006), p. 217; Daniel Buda, Hristologia Antiohiană, Sibiu 2004, p. 219.

${ }^{78}$ Letter to Cosmas, VIII, in: Patrologia Orientalis, XIII, Paris 1919, p. 279. See a summary of the events (a Romanian translation to K.G. Holum, Theodosian Empresses) in: I. I. Ică jr, "Imnul Acatist - Mistagogie şi istorie", pp. 36-37.

${ }^{79}$ A. Atanassova, “Orthodox Women's Defense”, p. 140.
} 
The magnitude of Marian devotion, and also its political significance

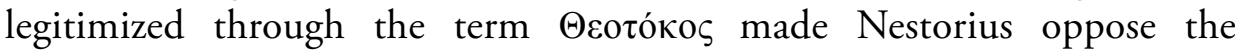
Mariological teaching developed in Constantinople and postulate a radical distinction between the two natures of Christ and, under the equivalence specific to the Antiochian School (essence = hypostasis = person), to affirm the existence of two persons in a relationship of voluntary union.

The Nestorian chronicler Barhadbshabba Arbaya (seventh century A.D.) neglects the dogmatic problem and presents the conflict between Pulcheria and Nestorius as the result of a moral crisis, after the Syrian preacher had found out that this "virgin" had seven lovers ${ }^{80}$ and had therefore removed the garment from the church and destroyed her image ${ }^{81}$, because "a virgin's robe was fitting gift for the Virgin's Son, but a glittering dress of a goodtime girl was hardly apposite" ${ }^{82}$. Thus the bishop harmed the Empress's image and authority that she had built through the institutionalization of Marian devotion. J.A. McGuckin even states that Theodosius brought Nestorius specifically to weaken the monastic hold over the church politics of the city and to estrange Pulcheria from the circle of power ${ }^{83}$.

But the Empress was not the only target of Nestorius' stand and his assault on the validity of the Theotokos title "could only have been interpreted by these powerful women (particularly the virgins and deaconesses among them) in the light of their own mimesis of the fertile and sacral virginity of the Mother of God. It seemed abundantly clear to them that Nestorius's assault on the honour of the Virgin went hand in hand with his attack on their own sources of honour and patronage, their own derived sacral basileia that

\footnotetext{
${ }^{80}$ Suidae Lexicon: Graece et Latine, "Poulcheria", tomus alterius, Halis et Brunsvigae, 1853,

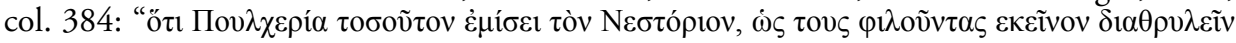

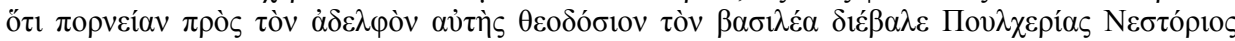

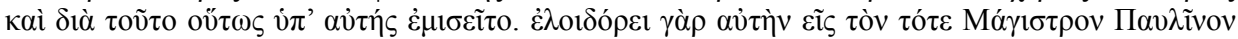
$\lambda \varepsilon \gamma o ́ \mu \varepsilon v o v "$.
}

${ }^{81}$ Barhadbshabba Arbaya, 27, p. 565

${ }^{82}$ J.A. McGuckin, "The Paradox of the Virgin-Theotokos", p. 19; Nestorius, Liber Heraclidis, I, 3, The Bazaar of Heracleides. Newly translated from the Syriac and edited with an introduction, notes \& appendices by G.R. Driver \& Leonard Hodgson, Oxford University Press, Oxford 1925, pp. 96-97. Nestorius defends himself before Cyril saying: "You have further with you against me a contentious woman, a princess, a young maiden, a virgin, who fought against me because I was not willing to be persuaded by her demand that I should compare a woman corrupted of men to the bride of Christ. This I have done because I had pity on her soul and that I might not be the chief celebrant of the sacrifice among those whom she had unrighteously chosen. Of her I have spoken only to mention [her], for she was my friend; and therefore I keep silence about and hide everything else about her own little self, seeing that [she was but] a young maiden; and for that reason. she fought against me. And here she has prevailed over my might but not before the tribunal of Christ"

${ }^{83}$ J.A. McGuckin, "Nestorius and the political factions", p. 8. 
reflected the glory of the Mother of God" ${ }^{84}$.

Thus Nestorius' reaction was not just a purely dogmatic stand, but also a political one. Kathryn Chew believes that the accusation brought by the bishop intended the erosion of Pulcheria's authority, which originated in her image as a virgin and chaste woman, the living icon of the Holy Virgin, and thereupon the preservation of her political power depended on maintaining the status of an immaculate virgin. This would explain her deep involvement in the Mariological and Christological dispute as an action determined less by her devotion to the true faith and more by her strong will to preserve the social and political position ${ }^{85}$. Of course, we must regard this information with suspicion since it is found only in the Nestorian sources, but we cannot ignore it when it provides some seemingly truthful details, which can weigh heavily in the reassessment of relations between the secular and the ecclesiastical power. It is beyond doubt that besides the dogmatic differences, the stake of

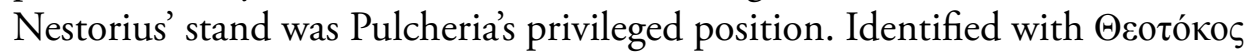
by $\pi \alpha \rho \theta \varepsilon v i \alpha$, the Augusta had institutionalized her status before and especially during the Nestorian crisis and tried to claim a certain supernatural power (in sense of $\beta \alpha \sigma i \lambda \varepsilon^{i} \alpha$ ) by merging the imperial power with the person of the Holy Virgin.

Considering the events after the Council of Ephesus (431 A.D.) it is obvious that Pulcheria integrated her personal devotion to the Virgin into the Constantinopolitan civic religion, transferring traditional, ceremonial and political elements into the sacred space, being generally found in the Christian processions and particularly in the ritual receiving of the holy relics, identical in shape and arrangement with the imperial adventus. The Empress sealed

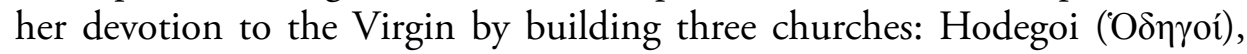

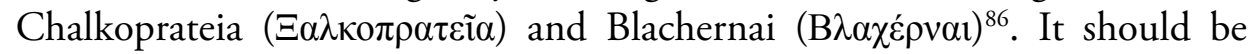
noted that each of these sanctuaries was dedicated to the Holy Virgin and was endowed with Marian relics that intensified the cult of the Virgin Mary and increased the masses' devotion to Theotokos.

As Blachernai church housed the "veil" of the Virgin, her "girdle"

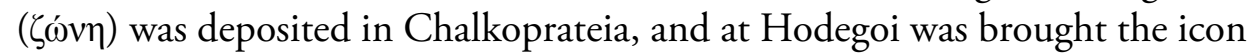
painted according to the Holy Tradition by St. Luke the Evangelist, entitled

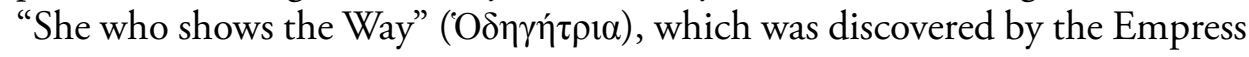

\footnotetext{
${ }^{84}$ Idem, "The Paradox of the Virgin-Theotokos", p. 20.

${ }^{85}$ K. Chew, "Virgins and Eunuchs: Pulcheria", p. 219.

${ }^{86}$ Some of these churches are attributed occasionally to Verina, the wife of Emperor Leo I (457-474 A.D.). See: Cyril Mango, "Constantinople as Theotokopolis", in: Maria Vassilaki (ed.), Mother of God: Representations of the Virgin in Byzantine Art, Milan 2000, pp.17-25.
} 
Eudocia in Jerusalem during her pilgrimage to Palestine (cca 438 A.D.) and was probably brought to Constantinople after her death (cca 460 A.D.).

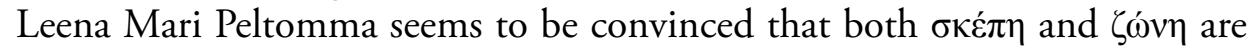
Pulcheria's "acquisitions", brought especially to strengthen the cult of the $\operatorname{Virgin}^{87}$.

\section{Conclusion}

The Virgin's cult has all the defining elements of a religion with strong civic character that is trying to be assimilated into the Constantinopolitan Christian society. In addition to the already usual ceremonial element and processions, specific churches and certain feast days dedicated prove that the Virgin's worship developed in a Christian sense through Pulcheria's imperial patronage. The Empress acted as a pontifex, institutionalizing the cult of the Virgin $^{88}$ and assisted the development of a Mariological doctrine on which

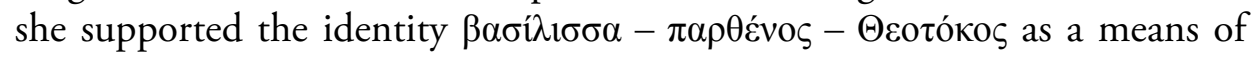
legitimating her own political power.

A closer look at the political, cultural and religious context indicates that the imperial power instrumentalized the Church and used the dogmatic teaching as ideological support. Pulcheria's actions indicate on the one hand a continuity of the religious identity's politicization, a dominant process throughout the Theodosian dynasty, on the other hand they show the development of a civic character of the Christian religion, incorporating elements meant to emphasize the presence of the emperor and Empress in the Church. Understanding this aspect is particularly important for the Orthodox Churches, which still sigh nostalgically for the "symphony" and the "Byzantine theocracy", although it is obvious that the Church was used. Her gain as divine-human institution was limited and it will continue to be so until it will understand that the body of Christ cannot be identified with a particular historical period or a particular political form and that the dogmatic teaching cannot be bound to or exhausted by previous paradigms of the relationship between church and state ${ }^{89}$, especially when the perception of that historical period is strongly deformed.

\footnotetext{
${ }^{87}$ L.M. Peltomma, The Image of the Virgin Mary, note 137, p. 77.

${ }^{88}$ V. Limberis, Divine Heiress. The Virgin Mary, p. 59.

${ }^{89}$ Pantelis Kalaitzidis, Orthodoxy and Political Theology, Geneva 2012, pp. 136-138.
} 